\title{
BIOSTIMULANT EFFECT OF SEAWEED EXTRACTS APPLIED ON BEANS (Phaseolus vulgaris L.)
}

Levi Pompermayer Machado ${ }^{1}$, Nair Hildelgard Soares dos Santos ${ }^{2}$, Kathiani Victor Bastos ${ }^{3}$, Dulcileia Marchesi Costa ${ }^{4}$

\footnotetext{
${ }^{1}$ Professor Doutor da Coordenadoria de Engenharia de Pesca na Universidade Estadual Paulista (UNESP), Câmpus de Registro - SP. E-mail: levipmachado@gmail.com

${ }^{2}$ Especialista e Gestão Ambiental no Instituto Federal de Educação, Ciência e Tecnologia do Espírito Santo (IFES), Vitória - ES.

${ }^{3}$ Mestranda em Oceanografia Ambiental na Universidade Federal do Espírito Santo (UFES), Vitória - ES.

${ }^{4}$ Professora Mestre do Curso de Especialização em Gestão Ambiental no Instituto Federal de Educação, Ciência e Tecnologia do Espírito (IFES), Vitória - ES.
}

\begin{abstract}
The present study evaluated the biostimulating effect on seed germination and initial vegetative development of Phaseolus vulgaris L. bean seedlings in response to the application of the aqueous extract of Osmundaria obtusiloba (C. Agardh) RE Norris (Rhodophyta) and Sargassum vulgare C. Agardh Ochrophyta), relating the activity with the contents of proteins and carbohydrates of extracts. Seaweed dried biomass of macroalgae were extracted at the concentration of $500 \mathrm{~g} \mathrm{~L}^{-1}$ in distilled water, this concentration was considered $100 \%$. After was prepared in dilutions of $25 \%, 50 \%$, and $0 \%$ (negative control) for each species. The experiment was conducted with 140 bean seeds in transparent plastic boxes kept in incubators under a12 hour photoperiod at the temperature of $25^{\circ} \mathrm{C}$ for 15 days. During this time, the germination percentage, germination speed and vigor of the seedlings (shoot length $\mathrm{x}$ radicle length) were assessed, as well as the sugar and total protein content of each seaweed extract. The results indicated that the development of seedling aerial biomass was 1.8 times higher with the extract at $25 \%$ concentration of $O$. obtusiloba than with the negative control. There were no changes in the germination parameters. Therefore, the $O$. obtusiloba extract showed a more positive effect on initial development than that of $S$. vulgare. The $O$. obtusiloba extract contained $160 \mathrm{mg} \mathrm{L}^{-1}$ while that of $S$. vulgare contained $80 \mathrm{mg} \mathrm{L}^{-1}$ total soluble proteins, indicating that protein content might be indicative of seaweed potential for application in agriculture.
\end{abstract}

Key words: Bioestimulants. Proteins. Sargassum vulgare. Osmundaria obtusiloba.

\section{EFEITO BIOESTIMULANTE DE EXTRATOS DE MACROALGAS APLICADOS EM FEIJÃO (Phaseolus vulgaris L.)}

RESUMO: O presente estudo avaliou o efeito bioestimulante na germinação das sementes e no desenvolvimento inicial vegetativo de plântulas de feijão Phaseolus vulgaris $\mathrm{L}$ em resposta da aplicação do extrato aquoso de Osmundaria obtusiloba (C. Agardh) R.E. Norris (Rhodophyta) e Sargassum vulgare C. Agardh (Ochrophyta), relacionando a atividade com os conteúdos de proteínas e carboidratos dos extratos. Biomassa seca das macroalgas foi Cultura Agronômica, Ilha Solteira, v.27, n.1, p.101-110, 2018 
extraída na concentração de $500 \mathrm{~g} \mathrm{~L}^{-1}$ em água destilada, essa concentração foi considerada $100 \%$. Em seguida foram preparados os tratamentos nas diluições de $25 \%, 50 \%$ e o controle negativo $(0 \%)$ para cada espécie de macroalga. O ensaio foi conduzido com 140 sementes de feijão em caixas gerbox transparentes mantidas em incubadoras com fotoperíodo de 12 horas na temperatura de $25^{\circ} \mathrm{C}$, por 15 dias. Durante o período foi avaliada a porcentagem de germinação, índice de velocidade de germinação e vigor das plântulas (comprimento parte aérea $\mathrm{x}$ radícula) e quantificação de açúcares e proteínas totais de cada extrato das macroalgas. Os resultados indicaram o desenvolvimento da parte aérea e biomassa das plântulas 1.8 vezes superior na concentração a $25 \%$ para o extrato de O. obtusiloba, sem alterações nos parâmetros de germinação. $\mathrm{O}$ extrato de $O$. obtusiloba apresentou um melhor desenvolvimento inicial. O extrato de $O$. obtusiloba apresentou $160 \mathrm{mg} \mathrm{L}^{-1}$ enquanto o de $S$. vulgare $80 \mathrm{mg} \mathrm{L}^{-1}$ de proteínas solúveis, indicando que esse parâmetro pode ser indicativo de macroalgas com potencial aplicação na agricultura.

Palavras-chave: Bioestimulantes. Proteínas. Sargassum vulgare. Osmundaria obtusiloba.

\section{INTRODUCTION}

The application of marine macroalgae in agriculture has historical records prior to 1950 (CRAIGIE, 2011). Initially, its benefits in terms of growth, health and yield of agricultural crops have been attributed to the extra supply of essential nutrients, which improves soil structure and water-holding capacity (KHAN et al., 2009). It was later determined that seaweed compounds present biostimulant and/or fertilizing properties that stimulate growth and exert protective effects against environmental stresses. These, in turn, promote an increase in agricultural productivity and prevent the excessive application of pesticides (VERA et al., 2011).

In seaweed extracts, the presence of plant growth regulators (cytokinins, auxins, gibberellins, betaines) (DURAND et al., 2003), macronutrients, micronutrients, protein and polysaccharides (KHAN et al., 2009) stand out. These components, although not considered essential, stimulate the development and induce environmental stress defense mechanisms in plants These molecules, by means of cell signaling, could stimulate physiological processes which generate antibiotic response, foster defense mechanisms and promote increased resistance (PAULERT et al., 2009).

Unlike chemical fertilizers, extracts derived from macroalgae are highly biodegradable, potentially less toxic and have less impact on the environment (RATHORE et al., 2009). Since organic agriculture emphasizes technologies with low environmental impact, the use of algae-based biostimulants shows high potential for application as inputs for organic crops (KUMAR e SAHOO, 2011; ARIOLI et al., 2015).

The popularization of healthier diets in view of the impact caused by chemical fertilizers and pesticides has also increased the demand for environmentally friendly and 
economically viable products. In this sense, Seaweed Extracts are a relevant input alternative aiming toward more sustainable production modelse (PINTO et al., 2010).

Most of seaweed-based agricultural biostimulant products are extracted from brown algae, especially kelps species (CRAIGIE, 2011). However, this group of marine macroalgae is not available on the Brazilian coast. Among the native species, the genus Sargassum (Ochrophyta, Class Phaeophyceae and Order Fucales) was highlighted by potential biostimulation applied to agriculture (AYMEN et al., 2014; SALMA et al., 2014).

The present study evaluated the total soluble protein and carbohydrates contend of aqueous extracts of Sargassum vulgare (Phaeophyta) and Osmundaria obtusiloba (Rhodophyta) and effects of application of these extracts on the seed germination and initial vegetative development of the common bean, Phaseolus vulgaris, to determine new native marine macroalgae candidates with potential for the marine agricultural biostimulants products.

\section{MATERIAL AND METHODS}

\section{Seaweed collection and processing}

The seaweed was collected in lateritic cliffs from Manguinhos beach (20 11' $12^{\prime \prime} \mathrm{S}$ $40^{\circ} 11^{\prime} 24^{\prime \prime O}$ ), in the municipal area of Serra, State of Espírito Santo, Brazil. The specimens were transported alive to the Laboratory of Aquatic Ecology of the University of Espírito Santo - UFES (MACHADO et al., 2011). In the laboratory, the seaweed was washed under running water for removal of epiphytes and sand particles. The samples were placed in plastic containers and shade dried for 24 hours at $30^{\circ} \mathrm{C}$.

\section{Preparation of aqueous extracts}

The seaweed's aqueous extracts were obtained by adding 1 liter of distilled water at $60^{\circ} \mathrm{C}$ for 45 minutes to $500 \mathrm{~g}$ of dried mass, which was afterward filtered through filter paper and stored at $4{ }^{\circ} \mathrm{C}$ (ANISIMOV e CHAIKINA, 2014). These extract, concentration of 0.5 g.mL ${ }^{-1}$, was considered the concentration $100 \%$.

\section{Germination experiment}

To experiment the seaweed extracts were diluted to the concentrations of $25 \%$ and $50 \%\left(0.125\right.$ and 0.25 g. $\mathrm{mL}^{-1}$ respectively) in distilled water. Additionally, were applied extract at $100 \%$, and the negative control $(0 \%)$. The experiment was conducted in the Laboratory of Plant Ecophysiology following a completely randomized design. The 20 bean seeds of "carioca" kind (obtained at the local market, of the LIVIA ${ }^{\circledR}$ brand) were placed in transparent boxes lined (20 seeds per box) with blotting paper, moistened with $5 \mathrm{~mL}$ distilled water. These were kept in Biochemical Oxygen Demand germinators under a 12hour photoperiod (light/dark) at temperatures of $25 \pm 2{ }^{\circ} \mathrm{C}$. Algae extracts were applied in the amount of $3 \mathrm{~mL} . \mathrm{d}^{-1}$ with a water sprayer. The harvest was carried out 15 days after

Cultura Agronômica, Ilha Solteira, v.27, n.1, p.101-110, 2018 
sowing. Experiments were conducted in three replicates $(n=3)$ simultaneously for all treatments.

\section{Analysis of seed germination}

The germination was defined as the moment of radicle emergence, these features evaluated were: a) germination percentage - global percentage value of germinated seeds after 15 days), b) germination speed - rate of germination was calculated by dividing the number of germinating seed each day by the number of days and summing the values and c) vigor of seedlings - shoot length $\mathrm{x}$ radicle length (MAGUIRE, 1962).

\section{Data analysis}

The experiment was conducted with a completely randomized design. The Tukey multiple comparison was used test the significance of the differences between treatments. Analyses were performed with ASSISTAT software (version 7.6). Data were analyzed using Assistat Software Version 7.7 - Universidade Federal de Campina Grande, PB, Brazil. Oneway analysis of variance (ANOVA) was performed when statistically significant differences were detected by Tukey's test. Differences were considered significant at a minimum level of $\mathrm{p}<0.05$.

\section{Quantification of proteins carbohydrate is seaweed extract}

The aliquot of $1 \mathrm{~mL}$ of seaweed extract $(\mathrm{n}=3)$ were used to determine total soluble protein and total soluble carbohydrate concentration based on the standard curve of absorbance in spectrophotometer as $595 \mathrm{~nm}$ and $490 \mathrm{~nm}$ respectively, as a function of the concentration of bovine serum albumin (BSA) and glucose which featured a linear correlation coefficient of 0.98 (DUBOIS et al., 1956; BRADFORD, 1976).

\section{RESULTS AND DISCUSSION}

\section{Germination}

The germination percentage showed no significant difference between the control and the treatments with the aqueous extracts of seaweed $(\mathrm{F}=2.33, \mathrm{p}=0.08)$. The values of $88 \%$ and $81 \%$ were obtained, respectively, for the treatment with the extracts of $S$. vulgare and of O. obtusiloba, while the control treatment resulted in $85 \%$ germination (Figure 1).

The results indicated the absence of an allelopathic effect from the extracts of $O$. obtusiloba and $S$. vulgare. This contrasts with previous studies showing a positive allelopathic effect in response to a commercial product using brown seaweed Ascophylum nodosum (GEHLING et al., 2014). Our results also differed from those obtained by Salma et al. (2014) who detected a 5\% increase in the germination percentage and a decrease of 1.28 days in the average emergence speed in response to the extracting of $S$. vulgare in two bean cultivars. 
The extract of $S$. plagiophyllum increased the germination percentage of Vigna radiata (mung bean) by $80 \%$ (KAVIPRIYA et al., 2011), while the extract of S. vulgare increased the germination percentage of Solanum lycopersicum L. (tomato) by 5\% (AYMEN et al., 2014). These responses are associated with an increased expression of genes linked to the endogenous production of auxin and cytokinin, hormones related to vegetable development (KHAN et al., 2009).

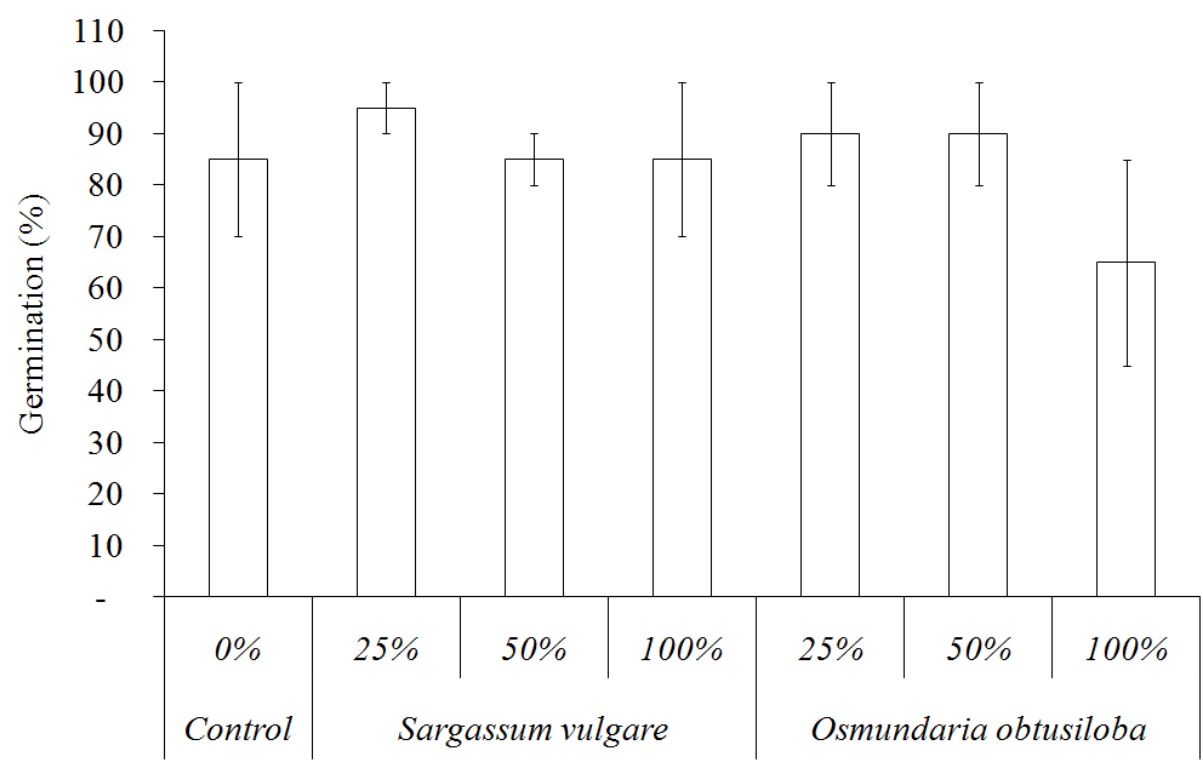

Figure 1. Germination percentage of Phaseolus vulgaris seeds subjected to different treatments with seaweed extracts and negative control. Bars represent the standard deviation of the mean $(\mathrm{n}=3)$.

Despite the tested extracts not having expanded bean seed germination, the results obtained are relevant since they attest to the possibility of a negative allelopathy promoted by seaweed extract (MACÍAS et al., 2008). It should be emphasized that, even in the presence of some bioactive compounds, the responses of plants can vary since they depend on the method (seed treatment, foliar and/or spray irrigation), dosage and frequency of the application (CARVALHO e CASTRO, 2014).

\section{Germination speed}

At the concentrations tested, the seaweed extracts did not promote any changes in the germination speed (Figure 2). The results of the analysis showed no significant difference between the negative control and the treatments $(\mathrm{F}=1.46, \mathrm{p}=0.30)$.

The highest values of germination speed were obtained at a concentration of $25 \%$, with decreasing speed at higher concentrations. Seaweed extracts can contain substances such as sugars, amino acids and organic acids which are considered osmotically active compounds. When in high concentrations, these compounds can influence germination and physiological processes (FERREIRA, 2004). This study shows that the application of SE is 
beneficial for agricultural use only at low concentrations, a result that is similar to that of other studies (ROBERTSON-ANDERSSON et al., 2006).

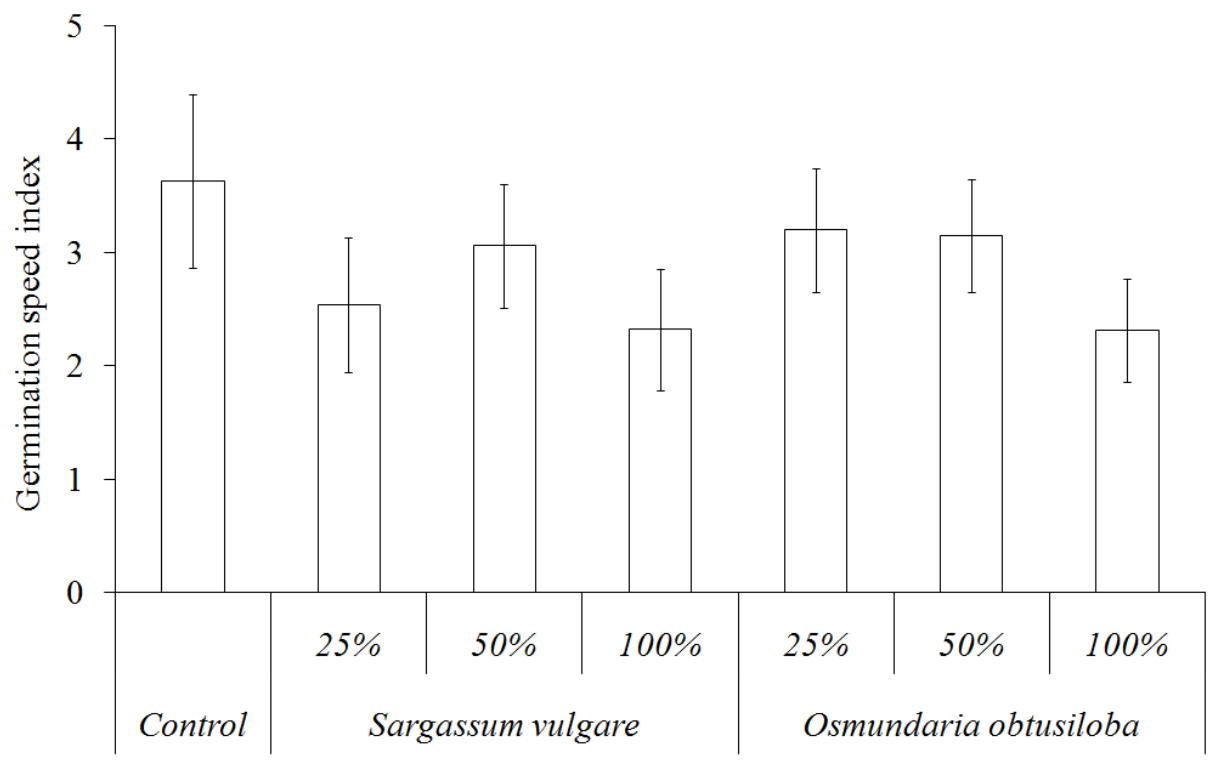

Figure 2. Germination speed index of Phaseolus vulgaris seeds subjected to different treatments with seaweed extracts and negative control. Bars represent the standard deviation of the mean $(n=3)$.

\section{Vigor of seedlings}

The seeds subjected to treatment with the extract of $O$. obtusiloba showed superior values of initial development when compared to the seeds treated with the extract of $S$. vulgare (Table 1). The treatment with $O$. obtusiloba suggests a significative biostimulant effect $(\mathrm{F}=3.9491 ; \mathrm{p}=0.0011)$ by having produced 1.8 times more biomass than the negative control, as well as greater shoot and radicle lengths.

Table 1. Mean values of seedling shoot length - SL (cm), radicle length - RL (cm) and fresh biomass - FB (g) of bean seedlings (Phaseolus vulgaris L.) $(\mathrm{n}=10)$ in response to seaweed extracts and control.

\begin{tabular}{ccccc}
\hline Treatment & Concentrations & SL $(\mathbf{c m})$ & RL $(\mathbf{c m})$ & FB $(\mathbf{g})$ \\
\hline \multirow{3}{*}{ O. obtusiloba } & $25 \%$ & $4.36 \pm 1.01 \mathrm{a}$ & $6.23 \pm 0.56 \mathrm{a}$ & $0.68 \pm 0.05 \mathrm{a}$ \\
& $50 \%$ & $2.84 \pm 0.81 \mathrm{~b}$ & $5.32 \pm 0.58 \mathrm{a}$ & $0.51 \pm 0.05 \mathrm{~b}$ \\
& $100 \%$ & $1.67 \pm 0.16 \mathrm{bc}$ & $5.34 \pm 0.51 \mathrm{a}$ & $0.47 \pm 0.03 \mathrm{~b}$ \\
S. vulgare & $25 \%$ & $2.59 \pm 0.48 \mathrm{~b}$ & $4.57 \pm 0.62 \mathrm{ab}$ & $0.59 \pm 0.04 \mathrm{ab}$ \\
& $50 \%$ & $1.21 \pm 0.31 \mathrm{bc}$ & $3.07 \pm 0.34 \mathrm{bc}$ & $0.51 \pm 0.04 \mathrm{~b}$ \\
Control & $100 \%$ & $0.06 \pm 0.02 \mathrm{c}$ & $1.57 \pm 0.07 \mathrm{c}$ & $0.47 \pm 0.04 \mathrm{~b}$ \\
& $0 \%$ & $2.42 \pm 0.87 \mathrm{~b}$ & $5.55 \pm 0.69 \mathrm{a}$ & $0.51 \pm 0.04 \mathrm{~b}$
\end{tabular}

Values followed by equal letters do not differ statistically for the parameter as evaluated by the Tukey test with a significance of $1 \%$. 
Other studies have also attested to the beneficial effect of biostimulants on the germination and development of several plants like peppers (Capsicum annuum L.), which got $100 \%$ in the culture yield (SIVRITEPE et al., 2003); beans (Phaseolus vulgaris L.), with an increase of 24\% (TEMPLE e BOMKE, 1989); and potatoes (Solanum tuberosum L.), with a $14.67 \%$ increase (SARHAN, 2011). In addition, Paulert et al. (2009) found that the spraying of algal extract stimulates the physiology and increases the dry weight of bean plants by approximately $20 \%$.

The extract of $S$. vulgare did not promote significant differences in the length of the root system or of the shoot as the extract of $O$. obtusiloba did. The results for $S$. vulgare are equivalent to those of the negative control. The result differed from that obtained for the brown seaweed extract, $A$. nodosum, which prompted a reduction of $12 \%$ in the growth of cashew seedlings when compared to the control (GARCIA et al., 2014).

\section{Total concentration of proteins and sugars of seaweed extract}

The concentration of total proteins $(\mathrm{F}=527.1485, \mathrm{p}=0.0001)$ and of total sugars $(\mathrm{F}=$ 9.1351, $\mathrm{p}=0039$ ) of the $O$. obtusiloba extract were significantly higher than those of the $S$. vulgare extract (Figure 3).
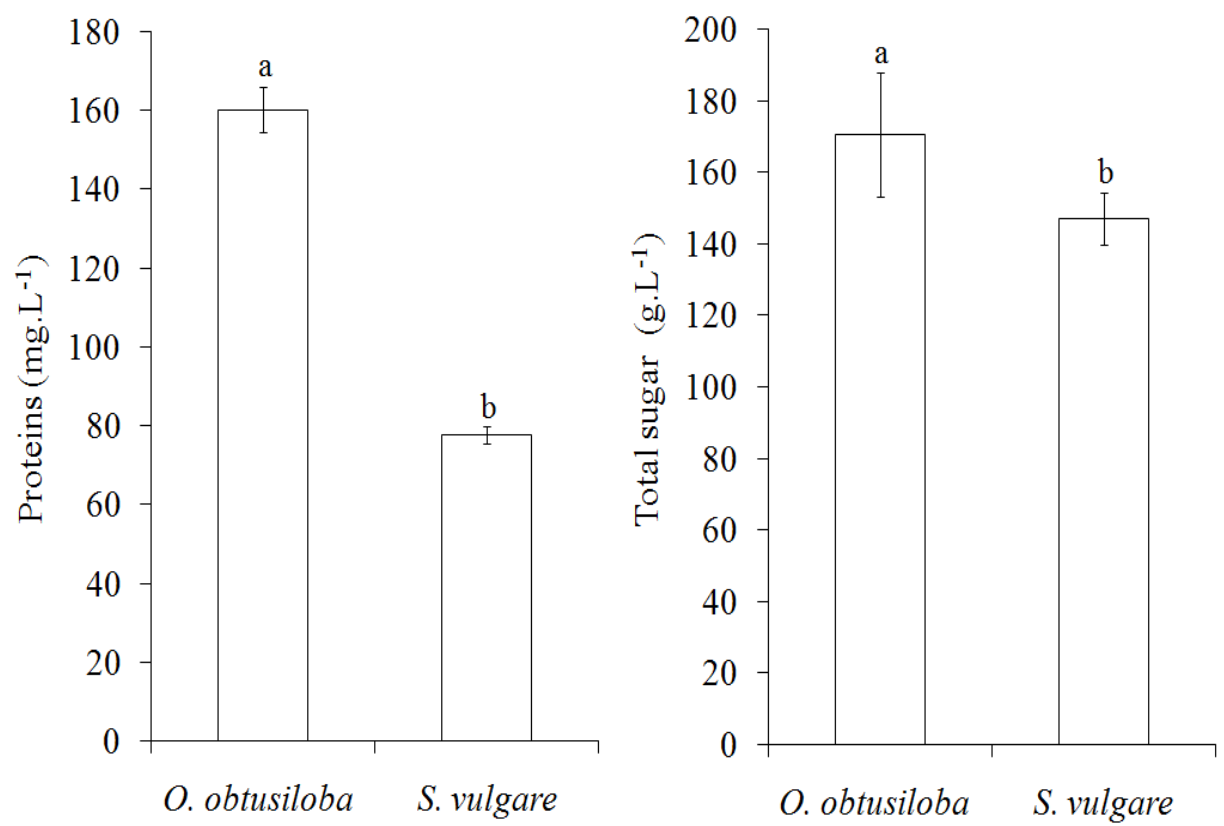

Letters indicate statistically significant differences for the parameter as evaluated by the Tukey test with a significance of $5 \%$.

Figure 3. Mean concentration of total proteins $\left(\mathrm{mg} \mathrm{L}^{-1}\right)$ and total sugars $\left(\mathrm{g} \mathrm{L}^{-1}\right)$ in the extracts of $O$. obtusiloba and $S$. vulgare $(\mathrm{n}=3)$.

Protein values are two times higher in the $O$. obtusiloba extract than in the $S$. vulgare extract. This higher protein concentration may account for the superior vigor and growth of seedlings of $P$. vulgaris in response to the extract of $O$. obtusiloba (CALVO et al., 2014). Such high protein content is common in the genre Osmundaria (SILVA et al., 2002). These

Cultura Agronômica, Ilha Solteira, v.27, n.1, p.101-110, 2018 
results suggest that analysis of protein concentration might be a tool for selection of seaweed species with potential applications in agriculture.

\section{CONCLUSION}

The results suggest that aqueous extracts of seaweed show a biostimulant potential in the initial growth of bean seedlings. However, the application of high concentrations of extracts can be harmful to the development of the plant by inhibiting its growth. The concentration of seaweed soluble proteins in aqueous extract can be used as a parameter for the selection of native species with potential applications in agriculture. Extract from $O$. obstusiloba presented greater efficiency as biostimulant than that of $S$. vulgare (specie which has a record of use in agriculture). Finally, our results highlighting the importance of search in native seaweed species for innovation and development of new biostmulant products applied to agriculture.

\section{REFERENCES}

ANISIMOV, M. M.; CHAIKINA, E. L. Effect of seaweed extracts on the growth of seedling roots of soybean (Glycine $\max$ (L.) Merr.) seasonal changes in the activity. International Journal of Current Research and Academic Review, Tamilnadu, v. 2, n. 8, p.19-23, 2014.

ARIOLI, T.; MATTNER, S. W.; WINBERG, P. C. Applications of seaweed extracts in Australian agriculture: past, present and future. Journal of Applied Phycology, Galway, v. 27, n. 5, p. 2007-2015, 2015.

AYMEN, M. E.; SALMAB, L.; HALIMAB, C.; CHERIFA, H.; MIMOUN, H. Effect of seaweed extract of Sargassum vulgare on germination behavior of two tomatoes cultivars (Solanum lycopersicum L.) under salt stress. Octa Journal of Environmental Research, Dehradun, v. 2, n. 3, p.203-210, 2014.

BRADFORD, M. M. A rapid and sensitive method for the quantitation of microgram quantities of protein utilizing the principle of protein-dye binding. Analytical Biochemistry, Valhalla, v. 72, n. 2, p. 248-254, 1976.

CALVO, P.; NELSON, L.; KLOEPPER, J. W. Agricultural uses of plant biostimulants. Plant and Soil, Amsterdam, v. 383, n. 2, p.3-41, 2014.

CARVAlHO, A. E. M.; CASTRO, C. R. P. Extratos de algas e suas aplicações na agricultura. Piracicaba: ESALQ, 2014. 58 p. (Série Produtor Rural)

CRAIGIE, J. S. Seaweed extract stimuli in plant science and agriculture. Journal of Applied Phycology, Galway, v. 23, n. 3, p.371-393, 2011. 
DUBOIS, M.; GILlES, K. A.; HAMILTON, J. K.; REBERS, P. A.; SMITH, F. Colorimetric method for determination of sugars and related substances. Analytical Chemistry, Champaign, v. 28, n. 3, p.350-356, 1956.

DURAND, N.; BRIAND, X.; MEYER, C. The effect of marine bioactive substances (NPRO) and exogenous cytokinins on nitrate reductase activity in Arabidopsis thaliana. Physiologia Plantarum, Helsinki, v. 119, n. 4, p.489-493, 2003.

FERREIRA, A. G. Interferência: competição e alelopatia. In: FERREIRA, A.G.; BORGHETTI, F. Germinação: do básico ao aplicado. Porto Alegre: Artmed, 2004. cap.16, p.251-262.

GARCIA, V. G. K.; SILVA, C. P.; CUNHA, M. C. S.; NASCIMENTO, C. D. V.; TOSTA, M. S. Extrato da alga Ascophyllum nodosum no desenvolvimento de porta enxertos de cajueiro. Enciclopédia Biosfera, Goiânia, v. 10, n. 19, p.1706-1715, 2014.

GEHLING, M. V.; BRUNES, A. P.; DIAS, L. W.; AISENBERG, G. R.; AUMONDE, T. Z. Desempenho fisiológico de sementes de trigo tratadas com extrato de alga Ascophyllum nodosum (L.). Enciclopédia Biosfera, Goiânia, v. 10, n. 19, p.743-750, 2014.

KAVIPRIYA, R.; DHANALAKSHMI, P. K.; JAYASHREE, S.; THANGARAJU N. Seaweed extract as a biostimulant for legume crop, green gram. Journal of Ecobiotechnology, Humnabad, v. 3, n. 8, p.16-19, 2011.

KHAN, W.; RAYIRATH, U. P.; SUBRAMANIAN, S.; JITHESH, M. N.; PRASANTH, R. P.; HODGES, D. M.; CRITCHLEY, A. T.; CRAIGIE, J. S.; NORRIE, J.; PRITHIVIRAJ, B. Seaweed extracts as biostimulants of plant growth and development. Plant Growth Regulation, Berlim, v. 28, n. 4, p.386-399, 2009.

KUMAR, G.; SAHOO, D. Effect of seaweed liquid extract on growth and yield of Triticuma estivum var. Pusa Gold. Journal of Applied Phycology, Galway, v. 23, n. 2, p.251-255, 2011.

MACHADO, L. P.; SANTOS, R. B.; BISPO, W. M.; MATSUMOTO, S. T.; GANASSALI JÚNIOR, L. F. O.; REIS, F. O. Triagem de macroalgas com potencial antifúngico no controle in vitro da antracnose do mamoeiro (Carica papaya L.). Current Agricultural Science and Technology, Pelotas, v. 17, n. 4, p.463-467, 2011.

MACÍAS, F. A.; GALINDO, J. L. G.; GARCÍA-DÍAZ, M. D.; GALINDO J. C. G. Allelopathic agents from aquatic ecosystems: potential biopesticides models. Phytochemistry Reviews, Amsterdam, v. 7, n. 1, p.155-178, 2008.

MAGUIRE, J. D. Speed of germination-aid in selection and evaluation for seedling emergence and vigor. Crop Science, Madison, v. 2, n. 2, p.176-177, 1962.

PAULERT, R.; TALAMINI, V.; CASSOLATO, J. E. F.; DUARTE, M. E. R.; NOSEDA, M. D.; SMANIA JÚNIOR, A.; STADNIK, M. J. Effects of sulfated polysaccharide and alcoholic extracts from green seaweed Ulva fasciata on anthracnose severity and growth of

Cultura Agronômica, Ilha Solteira, v.27, n.1, p.101-110, 2018 
common bean (Phaseolus vulgaris L.). Journal of Plant Diseases and Protection, Braunschweig, v. 116, n. 6, p.263-270, 2009.

PINTO, P. A. C.; SANTOS, N. G. N.; GERMINO, G. F. S.; DEON, T. D.; SILVA, A. J. Eficiência agronômica de extratos concentrados de algas marinhas na produção da alface em Neossolo Flúvico. Horticultura Brasileira, Vitória da Conquista, v. 28, n. 2, p.3980-3986, 2010.

RATHORE, S. S.; CHAUDHARYB, D. R.; BORICHAB, G. N.; GHOSHB, A.; BHATTA, B. P.; ZODAPEB, S. T.; PATOLIA J. S. Effect of seaweed extract on the growth, yield and nutrient uptake of soybean (Glycine max) under rainfed conditions. South African Journal of Botany, Stellenbosch, v. 75, n. 2, p.351-355, 2009.

ROBERTSON-ANDERSSON, D. V.; BOLTON J. J; NJOBENI A.; LEITAO D.; ANDERSON R. J.; RUCK, K. Can Kelp Extract (KELPARK ®) be useful in seaweed mariculture? Journal of Applied Phycology, Galway, v. 18, n. 5, p.315-321, 2006.

SALMA, L.; AYMEN, E. M.; MAHER, S.; HASSEN, A.; CHÉRIF, H.; HALIMA, C.; MIMOUN, E. Effect of seaweed extract of Sargassum vulgare on germination behavior of two bean cultivars (Phaseolus vulgaris L) under salt stress. IOSR Journal of Agriculture and Veterinary Science, Dansa, v. 7, n. 2, p.116-120, 2014.

SARHAN, T. Z. Effect of humic acid and seaweed extracts on growth and yield of potato plant (Solanum tuberosum L.) Desireé cv. Mesopotamia Journal of Agriculture, Mosul, v. 39, n. 2, p.19-27, 2011.

SILVA, S. M. S.; HOLANDA, M. L.; VASCONCELOS, I. M.; BENEVIDES, N. M. B. Purificação e caracterização parcial de uma toxina protéica presente na alga Vidalia obtusiloba (Mertensex C. Agardh) J. Agardh. Teresina: Embrapa Meio - Norte. 2002. 25 p. (Documentos n. 72)

SIVRITEPE, N.; SIVRITEPE, H. O.; ERIS, A. The effect of $\mathrm{NaCl}$ priming on salt tolerance in melon seedling grown under saline conditions. Scientiae Horticulturae, Amsterdam, v. 97, n. 4, p.229-237, 2003.

TEMPLE, W. D.; BOMKE, A. A. Effects of kelp (Macrocystis integrifolia and Ecklonia maxima) foliar applications on bean crop growth. Plant and Soil, Amsterdam, v. 117, n. 1, p.85-92. 1989.

VERA, J.; CASTRO, J.; GONZALEZ, A.; MOENNE, A. Seaweed polysaccharides and derived oligosaccharides stimulate defense responses and protection against pathogens in plants. Marine Drugs, Basel, v. 9, n. 12, p.2514-2525, 2011.

Cultura Agronômica, Ilha Solteira, v.27, n.1, p.101-110, 2018 